\title{
A Note on Stalked Forms of Viruses
}

\author{
By C. F. ROBINOW \\ Department of Bacteriology and Immunology, University of Western \\ Ontario, London, Ontario, Canada
}

SUMMARY: The filamentous forms of fowl-plague virus, isolated from infected eggs by Flford and Dawson, may be similar in origin to the stalked forms of vaccinia virus, discovered in preparations of infected cells by Bland \& Robinow, who contended that they were elementary bodies attached to cytoplasmic threads derived from the host cell.

In a study of fowl-plague virus adsorbed on the membrane of laked fowl red cells, Dawson \& Elford (1949) found the normal round virus particles associated with hitherto unknown forms described as: '.. filaments up to $6 \mu$. in length and averaging $80 \mathrm{~m} \mu$. in width, which in some instances are terminated by a spherical mass $100 \mathrm{~m} \mu$. in diameter'. The very clear electron micrograph illustrating Dawson \& Elford's discovery, especially the long form extending for about $1.5 \mu$. beyond the edge of the red cell membrane in that photograph, calls to mind the stalked elementary bodies of vaccinia virus briefly noted by Bland \& Robinow (1939) in the following sentence, describing the appearance of rabbit cornea epithelial cells at a late stage of infection with the viris: 'Their surface is often covered with a fringe of short delicate threads of cytoplasm each of which may have a single elementary body forming a little knob at its end (fig. 16b).' The structures seen by Bland \& Robinow are illustrated in Figs. 1 and 2 of the present note. Both are photographs of epithelial cells in hanging-drop tissue cultures of rabbit cornea infected with vaccinia virus, fixed in situ with osmium tetroxide vapour and stained with Giemsa solution. Fig. 1 is here reprinted from our 1939 paper (with acknowledgements to the editors of the J. Path. Bact.); Fig. 2 has not been published before. Elementary bodies at the end of short stalks can be seen arising from the free edge of the infected cells. Four of these structures are visible in Fig. 1 ; two, perhaps three, in Fig. 2. Cells fringed with these stalked forms were frequent in tissue cultures in which the infection had been allowed to run its course.

Dawson \& Elford suggested, with due caution, that the long forms of fowl plague may be a phase in the growth of the virus. Their evidence is the similarity of the ordinary and the long forms with regard to their combination with red cells and antibody. Bland \& Robinow did not regard the stalked forms of vaccinia virus as a phase in virus multiplication. They interpreted the stalk as an extension of the cytoplasm of the infected cell, with the virus particle forming the knob. Perhaps the stalked forms ultimately break away from the cell surface. Such a course of events, assuming it to be true for fowl-plague virus, would explain the presence of long forms in the allantoic fluid of infected eggs. Studies with the electron microscope of virus-infected tissue cultures would permit the testing of this hypothesis, and would probably be of considerable usefulness in the study of the origin of the long forms of viruses. 


\section{REFERENCES}

Bland, J. O. W. \& Robinow, C. F. (1939). The inclusion bodies of vaccinia and their relationship to the elementary bodies studied in cultures of the rabbit's cornea. J. Path. Bact. 48, 381.

DAwson, I. M. \& ElFord, W. J. (1949). The investigation of influenza and related viruses in the electron microscope, by a new technique. J. gen. Microbiol. 3, 298.

\section{EXPLANATION OF PLATE}

Figs. 1, 2. Epithelial cells in tissue cultures of the rabbit's cornea $20 \mathrm{hr}$. after infection with vaccinia virus. Fixed in situ with osmium tetroxide vapour, stained with Giemsa solution. $\times 1700$.

(Received 17 October 1949) 
Journal of General Microbiology, Vol. 4, No. 2

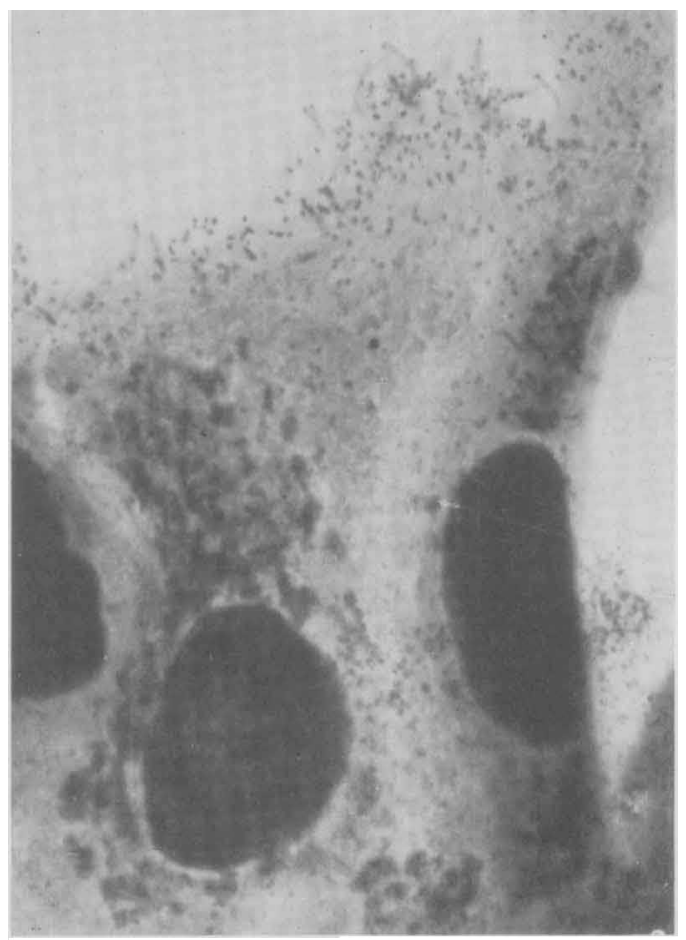

lig. 1
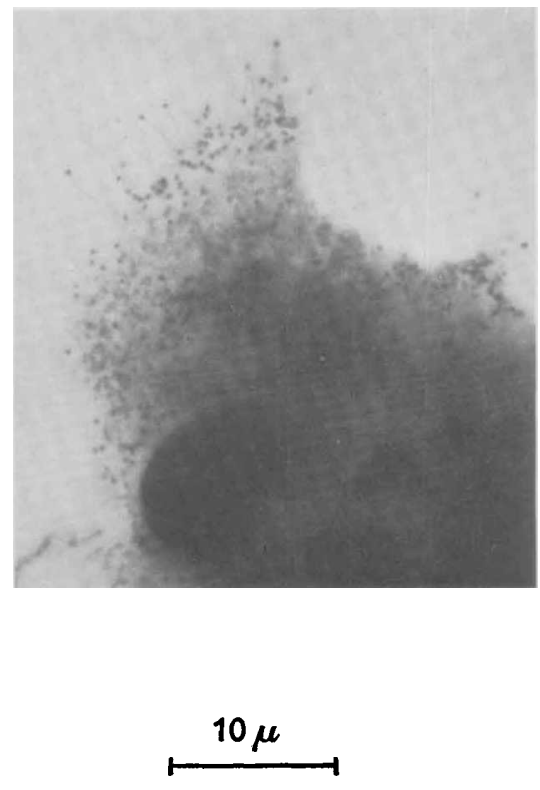

Fig. 2

C. F. Robinow-Stalked forms of viruses. Plate 1 